\title{
9. In Search of Healing in Transition: A Young Syrian Refugee's Experience of Reconciliation through Civic Engagement
}

NESREEN ELKORD AND LINA CHAKER

\begin{abstract}
This chapter explores the healing journey of a young refugee girl from wartorn Syria, through participation in the Tikkun Youth Project within the first year of her resettlement in Canada. Through a narrative approach, her story is considered from the social, cultural, and historical contexts, based on the work of Clandinin and Connelly (2000). Stemming from this theoretical framework, in-depth individual interviews with the young girl and participatory observation affords a better understanding of her transitional journey towards healing from the trauma of war, dislocation, and relocation. Her story characterizes impacts of civic engagement on the experiences of refugee youth in their search for healing and reconciliation.
\end{abstract}

Keywords: Youth civic engagement, social integration, narrative inquiry, healing and reconciliation.

This chapter sheds light on the healing journey and transitional experience of newcomer youth in civic engagement from the perspective of a young, female Syrian refugee, Randa. While it focuses on her experience of healing through civic engagement in the context of the Tikkun Youth Project in Canada, this chapter reflects a form of civic engagement that could help with the healing of any refugee youth, anywhere around the globe. Experiences of 
settlement vary based on several factors, including the types of support the young refugees receive from their new communities (Elkord, 2017).

Randa and her friends performed a drama play during the four-day Tikkun Youth Symposium in April 2017. With limited English language skills, an ongoing search for healing and a strong civic agency, they were able to bring to the forefront a view of war, survival, and reconciliation.

Before introducing Randa's narratives of lived experiences, we present a brief overview of the literature that guides this work, the method employed, and the backdrop of this narrative inquiry.

\section{Literature Review}

Three strands of literature set the context for this narrative study: refugee immigration and Canada's humanitarian role; the Syrian conflict; and youth civic engagement.

\section{Refugee Immigration and Canada's Humanitarian Role}

Large numbers of people around the world are forced to flee their homes every year in search of safety and protection. Over 65.6 million people worldwide were displaced as a result of war conflicts or persecution at the end of 2016 (United Nations, 2019). According to the Government of Canada (2017b), "[r]efugees are people who have fled their countries because of a well-founded fear of persecution. They are not able to return home" (The refugee system in Canada).

Canada maintains its well-respected international humanitarian reputation by providing thousands of refugees a safe haven through sponsoring their resettlement across the country. Over the last decade alone, Canada has welcomed thousands of refugee families from various countries affected by war or natural disasters, including Syria. In fact, the Government of Canada's (2017a) “\#WelcomeRefugees: Key figures" states that Canada resettled more than 40,000 Syrian refugees between November 4, 2015 and January 29, 2017. 


\section{The Syrian Conflict}

Prior to the rise of the destructive war, Syria was regarded as a heterogeneous country in terms of its religious diversity (Haddad, 2012; Khoury, 1991; Rabo, 2005). Politically, the Syrian regime was considered nondemocratic because of its one-family, non-elected rule extending over four decades. Over the years, military and intelligent services maintained the status quo through curbing opposition movements (George, 2003: Khoury, 1991), as was the case in the 1980s and most recently since 2011.

A youth led opposition movement began in the southern city of Dara'a, which gradually spread across most of the country and was faced with harsh regime-led persecution (Pace \& Landis, 2009). Consequently, as living circumstances became worse and lives of civilians were under constant threat, many escaped with no particular destination in mind. Many escaped to one of the neighbouring countries: Jordan, Lebanon, or Turkey. During these difficult times, most had struggled with limited access to basic education and human needs for long periods of time, and some had experienced separation from or loss of family members. They were placed in refugee camps until the UN arranged placements for them in other countries across the world. Once in the developed host countries, the responsibilities of the settlement of Syrian refugees, including their mental well-being and societal integration, emerged as key public concerns.

According to research, adolescent refugees resettling in a new country are more likely to experience academic and social challenges than their peers (e.g., Janzen \& Ochocka, 2003; Lee, 2005; Manavathu \& Zhou, 2012). This is partly due to untreated psychological trauma and the public's lack of understanding of refugee youth's pre-migration experiences and current needs (Ayoub \& Zhou, 2016). So much can be learned from stories told by refugee youth themselves.

\section{Youth Civic Engagement}

Young Syrian refugees in Canada begin a new chapter where they are forced to participate in regular life activities. They simultaneously face challenges of integrating into the Canadian school systems while trying to cope with 
the emotional distress caused by the traumatic experiences they faced in the war or in refugee camps (Ehntholt \& Yule, 2006).

Documenting the stories of Syrian youth before and after Syria's civil uprising is intimately related to youth civic engagement, and the modes of storytelling are comparable to civic engagement strategies that young Canadians use (Hamilton \& Flanagan, 2007). Randa and her friends gave new meaning to their shared traumatic experiences by writing and performing a drama play based on their stories. In doing so, they were motivated by the desire to reconcile the impacts of the struggles they have been through and to shift what they perceived as the public's negative perceptions of refugee youth as non-productive.

In re-telling Randa's life story in this chapter, we explore the power of storytelling that she has brought to Canadian and international audiences for healing and reconciliation.

\section{Method}

The method used in this inquiry is presented in four parts: description of the inquiry; overview of narrative inquiry; sources of evidence/tools of discussion; and trustworthiness.

\section{Description of the Inquiry}

This narrative inquiry with Randa reflects on a youth participatory endeavor supported by the Tikkun Youth Project. My colleague Lina and I were informed of the opportunity that the project was providing Syrian newcomer youth - a platform to tell their stories of war, migration, and reconciliation. We enthusiastically welcomed the idea and began planning. As a doctoral student at the time, my research interest in the lived experiences of newcomer youth, in conjunction with Lina's community volunteerism with Syrian newcomers, well-positioned us to utilize our resources to support the youth's goals. While the drama production was a brief 17-minute performance, recruiting the youth performers and drama experts, acquiring 
necessary funds, and the ongoing rehearsals took over six months of hard work.

Neither Lina nor I had any prior experience with theatre or drama performances, thus we reached out to Charlotte LeFrank who is the Diversity Outreach Coordinator at the Children's Aid Society and has extensive drama production expertise. Charlotte showed great passion and enthusiasm to support the youth in making their voices heard and helping them heal. The three of us met with the youth on a weekly basis to build rapport, share stories, write scripts, and rehearse. The high school youth required plenty of support to enable their meaningful participation.

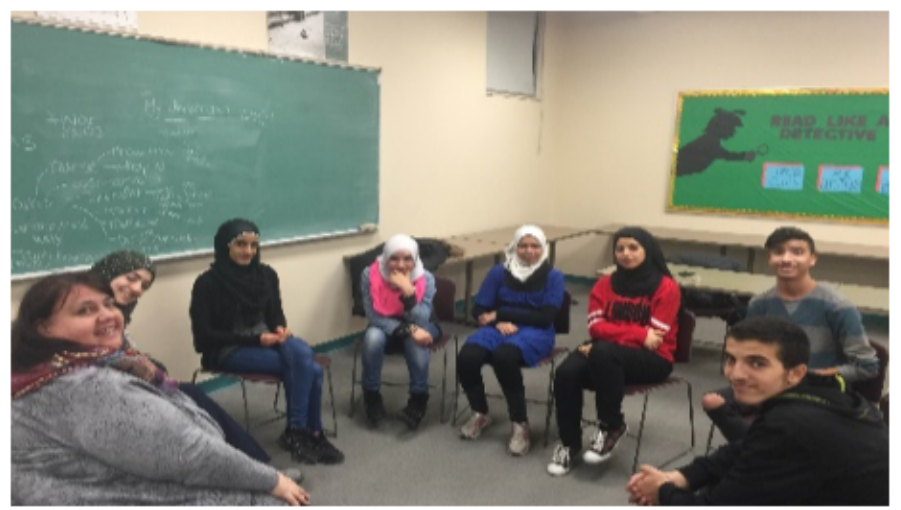

Figure 1. The youth meeting Charlotte for the first time.

Funding covering transportation and refreshment expenses came from the Multicultural Council of Windsor \& Essex County (MCC), an organization that serves newcomers in its efforts "to create a welcoming community for all through education, community engagement and the promotion of diversity and equality" (Multicultural Council of Windsor and Essex County, 2018, para. 1). Consent forms were signed, and agreements were made with the parents of the youth participants to allow their participation in the project. 


\section{Overview of Narrative Inquiry}

Narrative inquiry is both the method and form of this endeavor with Randa (Connelly \& Clandinin, 1990). Randa's narratives of lived experiences in search for healing in the transition is the phenomenon of the study, and it is the methodology used for collecting the stories and discussing them.

Dewey's (1938) notion of experiential knowledge, and that knowledge is both personally and socially developed, provided the basis for Clandinin and Connelly's $(1988,1992,2000)$ narrative inquiry - a form of inquiry premised on storytelling and sharing of lived experiences as a form of social action that prompts people to reflect on their beliefs and assumptions. Unlike other methodologies, narrative inquiry avoids judgement, jumping to conclusions, or translating lived experiences into "solvable problems" (Xu \& Connelly, 2010, p. 359). As such, Randa, the young participant, characterizes her act of storytelling and sharing of experiences as a form of thought-provoking civic engagement.

\section{Sources of Evidence/Tools of Analysis}

With a narrative approach, Randa's story of experience is informed by several sources of data, mainly observation and interviews (Connelly \& Clandinin, 1990). Lina, as a community volunteer, initially met Randa upon her arrival in Windsor in 2016, and later developed a close relationship with her at a summer camp for newcomer youth. At the summer camp, Lina co-facilitated a number of the youth activities including one that involved a living library. In the living library, the youth told stories of their pre-migration lives in Syria in an effort to support their healing and reconciliation process. This enabled Lina to gain some understanding of Randa's family life and pre-migration experiences.

Upon the invitation to participate in the Tikkun Youth Project in November 2016, Lina introduced Randa and her friends to me. The youth were motivated to adapt their stories from the living library into the form of a play which gave rise to the Tikkun drama performance sub-project. Over the period of the play project, we (Nesreen, Lina, and Charlotte) were able to develop a collaborative relationship with the youth participants as they felt 
their voices appreciated and their stories respected. At the conclusion of the Tikkun Youth Project, we stayed connected with the youth who often needed ongoing support.

On-going participant observation over a period of almost two years in various settings provided us with a collection of field texts (data) for the inquiry. I also conducted three open-ended in-depth interviews with Randa to support the development of her narrative and followed up with several conversations after the initial and modified drafts of the script were prepared. Most interviews and conversations were followed by discussions, reflections, and note-taking among Lina and I.

The field texts were then triangulated and transformed into research texts, which, in turn, gave rise to this chapter's theme of "in search of healing and reconciliation." Three tools of analysis were used to discuss the data: Broadening was used to situate the research texts in the social, historical trajectory of events that took place in Syria leading to the migration of Randa and her family; burrowing involved a deeper look at the tensions Randa experienced in the transition while coping with relocation challenges; and finally, storying and re-storying captured details of her journey in the transition as she made sense of her lived experiences and reconciled the past with the present (Ciuffetelli Parker \& McQuirter Scott, 2010; Craig, 2013). Storying and re-storying is not meant to provide answers; instead, it offers a means of deeper thinking and reflection.

Randa's life story is presented through a narrative design based on Clandinin and Connelly's (2000) three-dimensional narrative inquiry framework:

Dimension of temporality. Lived experiences must be plotted on a timeline to reflect and understand their meanings. Hence, we explore stories of Randa's life in the past to help make meaning of her current journey of healing in the transition.

Dimension of sociality. Randa's narrated stories reflect her social interactions with people in her family, school, and the wider community. The stories also inform how such interactions impacted her in the past and continue to impact her journey of healing. Such social experiences are a result of combinations of societal and personal factors including her norms, beliefs, and behaviours. According to Clandinin and Connelly (2000), "[i]n essence, narrative inquiry involves the reconstruction of a person's experience in relationship both to the other and to a social milieu" (p. 125).

Dimension of place. The term place entails the importance of 
different living situations, contexts, or environments in relation to experience and life learning. Thus, we explore Randa's lived experiences in Syria, in Jordan, in Canada, at home, at school, or outside of school.

\section{Trustworthiness}

The trustworthiness of this inquiry, as understood in narrative terms, has to do with its "lifelikeness" (Mishler, 1990). The aim of narrative inquiry is to explore the meanings and forms of understanding that participants express through stories (Coulter \& Smith, 2009; Feldman, Skoldberg, Brown, \& Horner, 2004). As Elbaz-Luwisch (2004) emphasizes, "[e]vents deemed worthy of being remembered and retold in story form are likely to be meaningful to the teller, and to reveal something important about how she understands her life" (p. 394).

Support for the discussions can be found in common understandings that transcend Randa's storied experiences over time. Thus, it is ultimately the readers who determine the trustworthiness of this inquiry and decide whether the lifelike representation of Randa, and her coming to see her role as socially engaged, contributes to the understanding of how young refugees experience healing in transition (Craig, 2013).

\section{Randa's Life - In Search of Healing in Transition}

Randa is an 18-year-old girl, enrolled in grade 11 at a public high school in the city of Windsor, Ontario. Randa spent most of her life in Syria where she lived with her mother and 2-years elder brother. Her father passed away when she was five, but her mother did everything she could to make Randa and her brother feel happy and fulfilled, to make up for this loss. 


\section{Randa's Life in Syria}

Randa was born and raised in Dara'a, a border city in Syria, where she lived with her small family in an owned apartment until late 2013. Randa's mother was a stay-at-home mom who dedicated her life towards looking after her two children with the financial support of her wealthy father. They lived a simple lifestyle in a rural setting in a small tight-knit community among family and neighbours who knew and cared for each other. Randa and her brother attended neighbouring schools and had many school and community friends. They both enjoyed school life where they excelled academically and were frequently recognized for their hard work ethic; this boosted their self-confidence and hopes for the future.

Randa's family life was stable until the rise of the civil war when the town's youth prompted a revolt in 2011. The conflict escalated quickly, and authorities began to arrest male youth in response. For the first few months, Randa's brother was always on the run as he hid from persecution at several of his relatives' and friends' houses. During this time, the family house was raided multiple times as officers demanded his arrest, among many other youths of the city. The family became separated and the pressure was heightened with multiple bombings in the neighbourhood, forcing Randa and her mother, among other neighbours, to leave their home in search of safer havens. They moved in with a number of relatives in other towns for several weeks at a time. When bombings in Dara'a slowed down, Randa and her mother would go back to their home until things became unbearable again. Throughout this period, Randa's brother would only briefly visit the family while cautiously avoiding public attention. Randa described this anxious time as she recalled a memory:

One day, my aunt and cousins were over for dinner. It was during the month of Ramadan, when family usually gathers to break the fast together. Suddenly, we were literally shaken by something that felt like a massive volcano eruption. We all ran up close and huddled in a tiny room for a few hours and waited to die any second.

She continued,

That night, I thought it would be the scariest night of my life, only to realize I would face bigger fears as time moved on. After leaving 
our house, I had to sneak back home a few times to get some of our belongings that we had initially left behind. I would sneak between narrow pathways with a friend or an aunt, going in the darkest of nights, hoping not to be shot by a sniper. We would only carry back the most precious items because our trembling legs could hardly carry us back.

Despite the harsh living conditions, Randa and her mother had no intention of leaving Syria - yet. They were expecting the war to end soon and their life to go back to normal. It was only when they reunited with her brother in a hospital after a few weeks of his usual disappearance - that her mother instantly made the decision to leave. Randa's brother was shot during a protest and her mother decided that she needed to protect the one other man left for the family. She immediately carried her son across the border, with his wounds still bleeding, in hope of saving his life.

\section{Randa's Life in Jordan}

Randa's mother took her son to Jordan where some of her late husband's family had moved earlier. The normal process for Syrian refugees in Jordan was to stay in refugee camps until UN representatives looked into each family's individual case and found appropriate placements to sponsor them across the world. For Randa's family, the process was not as traditional because her mother did not initially desire to be relocated to another country. She thought it would be best for her son to stay in Jordan, and for herself and Randa to return to Syria once it became safe to do so. These goals were difficult to achieve while remaining in a refugee camp. With the in-law's support, Randa's family was able to leave the premises and sneak into the city of Amman in Jordan where they had a place to stay and monetary donations to depend on. Randa described,

My mom and I stayed home throughout the whole period and hardly went out. We had a hard time accepting the new situation. It just felt humiliating enough having to leave home this way and sneaking into the country [Jordan] like criminals.

As time went on and Randa's brother healed, he went out looking for work to 
support himself and the family. It was technically illegal for him to be hired, but business owners were illegally hiring Syrian youth for cheap labour. $\mathrm{He}$ worked a number of jobs, earning just enough money to survive from day to day. During this time, Randa and her mother impatiently waited to go back to their home in Syria. However, eight months later, there were no signs of war ending any time soon in Dara'a and Randa was getting frustrated from missing out on school:

I thought I'd eventually be able to go back to my school in Dara'a once the war was over... It was a tough transition for me. I had suddenly left my home, my relatives, my school and friends without properly saying goodbyes or even preparing myself for the move. I thought it was going to be a temporary getaway!

She continued,

The owner of the private school I joined was very kind and generous. He insisted to enroll me without charging us any fees... We appreciated the support [lets out a sad sigh], but I hated every day at that school. I felt isolated as there were no other Syrian students... I felt like schoolmates were constantly pointing fingers at me and making up stories about what brought me and my family to their country.

Randa was only able to become friends with one classmate: "[t]he least privileged in class because she was the only one who accepted me" she explained. She had to redo grade 9 before moving on to grade 10 and later to grade 11:

I wasn't happy at school, but I certainly didn't want to stay at home any longer... At first, it was difficult to sit in class for hours after having been out of school for almost a year... I wasn't really ready to move on.

Randa went to school in Jordan for almost two years before her family received the phone call that changed their life forever. 


\section{Randa's Life in Canada}

As things continued to only get worse in Dara'a and life did not get any easier in Jordan, the family received an official phone call informing them that they had been selected for placement as refugees to Canada. Although they first hesitated, the family quickly decided to leave everything and everyone they had ever known behind, and to fly to the new world:

"It was scary. Things happened very quickly. All within one month!" Randa told me,

It was December, and I was studying for exams. We had to leave in the midst of everything... mama was afraid; she was so hesitant to accept the offer at first. Everyone she knew advised her to consider it an opportunity to start a new life since there was no going back to Syria any time soon and there were very few opportunities in Jordan, if any... I remember after the phone call, she sat on the floor in the kitchen and started crying. She recalled all the hardships [of relocating] we've been through since we moved to Jordan - she didn't want to restart all over again! On the other hand, my brother was eager to leave Jordan. He always felt unappreciated and overworked... we quickly packed a few items and flew away.

Randa and her family arrived in Windsor in January 2016: "Everything was different. The streets looked different, people looked at us differently... and we even had to dress differently because it was very cold" Randa described. They were temporarily placed in a motel for one month with a number of other newcomer Syrian families. It was a time of uncertainty for them all, yet a chance to connect with each other. Randa and her brother were expected to go to school right away, and her mother to join an English language learning program at one of the available settlement agencies in the city.

I didn't know what to expect at school. I was afraid and overwhelmed... I realized I had to adjust all over again, like I did when we went to Jordan. This time it would be harder, I thought, because I had to learn a new language. I would've stayed at home if I had the choice, but we were clearly told that school was mandatory... At least this time I wasn't going to be alone. 
Randa goes to high school in Canada. The high school Randa joined hosted a large number of the young Syrian newcomers that arrived in the city. She described, "At school, whenever I spotted a Syrian student, I felt at ease no matter how stressed I was... It made me feel at home. A feeling I longed for during the time I spent in Jordan."

Having lived similar experiences of war and relocation, Randa and a number of the other newcomer schoolmates were able to resonate with one another and develop close friendships:

We quickly bonded... we had all left our homes and spent several months or even years at one of the neighbouring countries before coming to Canada. We were all scared... Some had more tragic memories to live with, some lost family members, and others [youth] had to take care of terminally ill parents or siblings due to war injuries... We had little confidence, if any, that we could make it through.

They would meet up early in the morning at the bus stop to go to school together. Once at school, they would not waste an opportunity to support each other. Randa narrated,

They all became like family... I remember the first time I felt awkward when we went for lunch and I realized that I was 15 cents short after I placed my order; one of the boys quickly came up and handed the change to the cashier. In Syria, we were told that accepting money from anyone is an absolute shame because it's a form of pity... but in no-time I learned that among our group, things were different. That day, I felt like he was family.

While Randa quickly made friends upon arriving in Canada unlike Jordan, she had to cope with different types of challenges. She explained,

I need to work hard to adjust. It's a big transition coming from war where people were turned against each other. I still find it difficult to trust people at times... I remember one time my friends and I went to Tim Hortons for coffee, a police officer walked in and stood behind us in line. The moment we became aware of his presence, my friends and I quickly glanced at each other and a worried look masked our faces, and my legs started shaking. Very few people 
would understand this. We lived through times when officers were the ones arresting our brothers...

Describing school, Randa added,

It's also difficult when I can't express myself... it's difficult to learn a new language. Most of the time I'm afraid to talk to schoolmates who don't speak Arabic... but I feel obligated to clear some misunderstandings... One time, a video recording of one of the Syrian newcomer girls dancing in gym class went viral at school... some began to point fingers and criticize her for being upset about it. They didn't understand how culturally inappropriate this is for us... That day, I thought to myself, if we don't bring an understanding of our people, we can't blame others for having misconceptions!

While Randa faced challenges during the transition, she wholeheartedly continued the search for social integration and academic excellence. The clear eagerness and enthusiasm for civic engagement that she showed when I first met her brought many questions to my mind. I wondered what might have motivated her to dedicate time and effort for the project we were proposing!

\section{Participating in the Tikkun Play Project}

I was intrigued by the courage and enthusiasm Randa and her friends showed for sharing their lived experiences. They felt that their stories, which had already been documented in the form of a book and presented in the form of a living library during the summer camp that Lina was involved in, deserved a wider audience. They were concerned with their limited English skills and decided that they could more effectively express themselves in the form of a play featuring common war experiences and stages of their migration and gratitude.

Over the period of the project, we all bonded and many of the youth repeatedly expressed how excited they would be to come to the rehearsals: "We would be looking forward to our meetings, as our fun getaway from school and everything else" Randa said. 


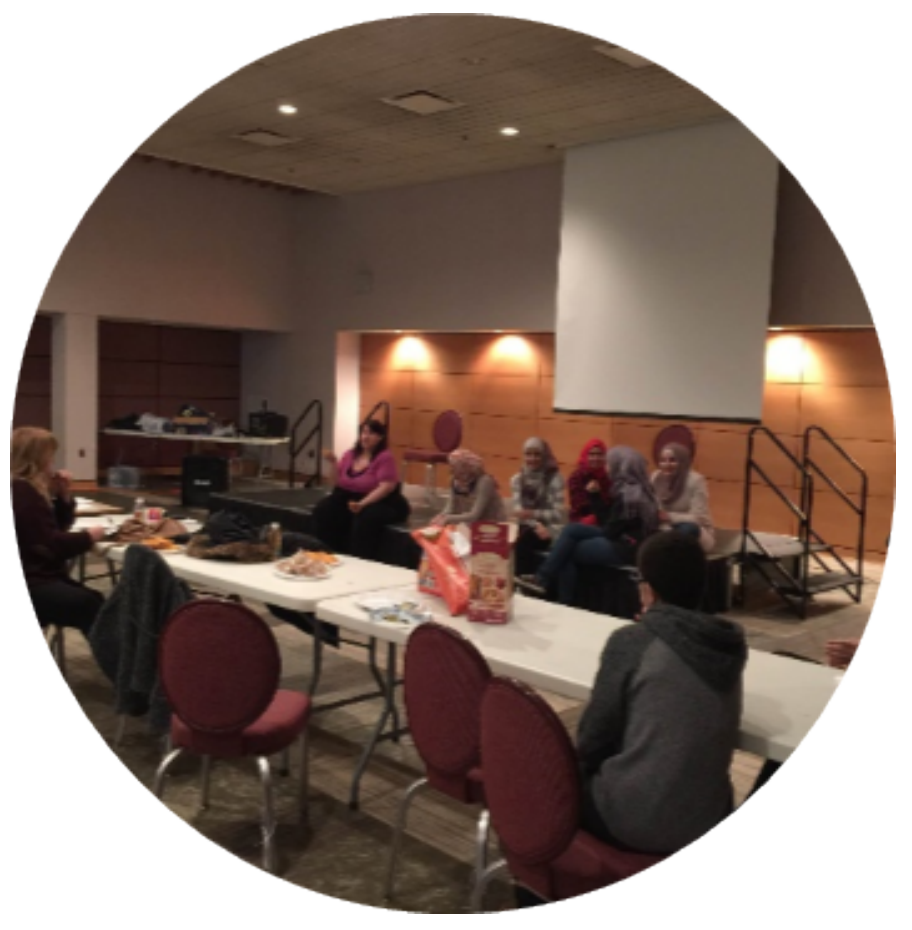

Figure 2. At a rehearsal.

Coming to the rehearsals regularly brought me and my friends closer together. We learned so much about each other's lives... Participating in this project has allowed me to see my strengths. Only then I began to accept my shortcomings and focus more on what I could do rather than what I couldn't... Speaking in English during the rehearsals boosted my confidence. I started to realize how capable I was and began to have more courage to speak with my English-speaking schoolmates at school. I would go back to school on Mondays and tell my ESL teachers about our rehearsals... I was also becoming more open to people's questions. In the past, I was more reserved... Sharing details about my life in the project made me realize that I had nothing to be ashamed of. I even became proud of how resilient I have grown after all I've been through.

Although the youth enjoyed working on the project, not everyone was able 
to stay as committed as we had initially hoped. As time passed, we lost four of the youth who were having difficulty in balancing school with this project while also attending to other commitments. This made it even more important to keep the remaining eight youth committed and enthusiastic.

Logistical challenges. The nature of the drama project demanded a lot of in-person time that could not be replaced by individual contributions from a virtual distance. All the participants needed to be together and rehearsing at the same time for it to work. This implied our full commitment as facilitators as well. With increasing schoolwork demands, it became difficult to meet after school. We started to meet on weekends, which made the youth unable to walk to university campus to meet; instead, they would need to be driven. We would arrange to pick them up from their residences and drive them back once done. We had a generous community member, Laura SoutarHasulo, eventually join the team and assist with transportation and logistics as rehearsals were on-going. This needed coordination and much collaboration among all the team members.

At times we had to speak to some of the parents to build rapport and assure them that their children were contributing to a worthy cause. Some parents became concerned that the time the youth were spending in this project would negatively impact their school work. However, as the project became a valuable goal for the youth who remained committed, they worked hard to prove that it would only impact their overall progress positively. Randa explained,

On one of our rehearsals, I was nervous about a big chemistry test I had to write the next day... I remember how the words of inspiration that I heard from the team helped me calm down and motivated me to do the best I could... the next day I did very well and scored 94/ 100. I was so proud and excited; I quickly texted you and Charlotte to tell you how well I did. I felt like our play team had become my second family... I once again became motivated to do well at school like the old days because I knew there were people who would be happy and proud to see me succeed.

Healing and reconciliation. There were several challenges to be overcome in drafting the play scripts, discussing the scenes to be performed, and even conducting the rehearsals. We needed to be mindful of the emotions of the youth as they recalled and told their experiences in the war. 
To overcome grief from recalling negative experiences, we incorporated scenes of the participants who had left the project and were unable to perform in the play in order to de-sensitize the story. This helped make the story being narrated less personal, as it was not a factual recollection of any one single story but a collective exercise to re-define their mutual experiences through a lens they were comfortable sharing. We also incorporated scenes that provided comic relief to emotionally counteract negative memories. For example, one of the scenes describing the educational goals of youth, poked fun at the high expectations of society

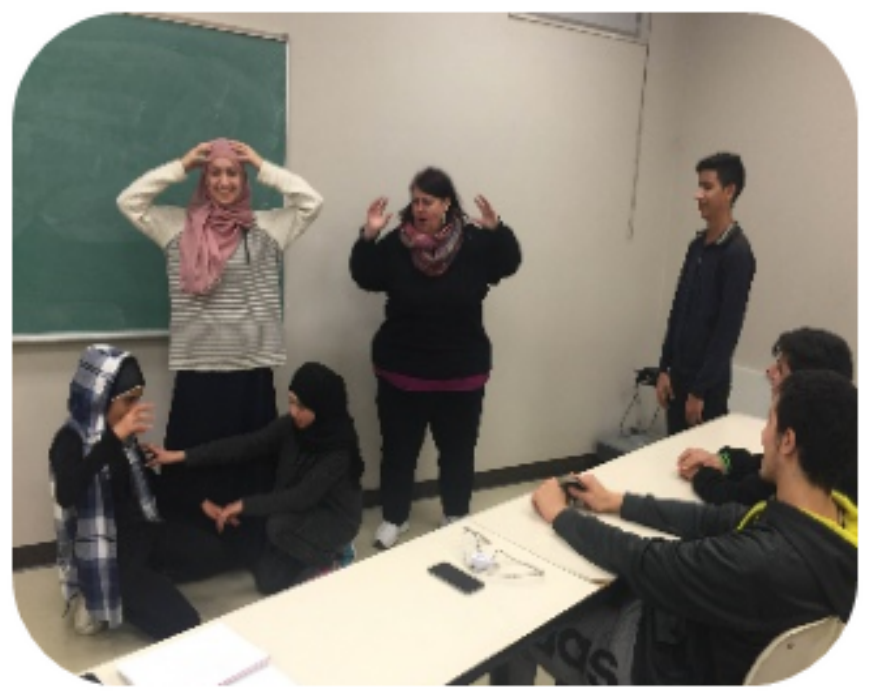

Figure 3.

Ice-breaker activity at a rehearsal.

and parents: [Click here to see the "It's my dream, not yours" scene]. Another scene created opportunity for the youth to laugh about the common language learning challenges they were experiencing during the transition. We counteracted their lack of confidence by laughing at the difficulty of pronouncing some words, especially ones with the letter "p", as they would pronounce it as a "b" instead. We also made sure to begin rehearsals with an ice-breaker activity and to conclude every time with practicing the last scene of the play. Even when the youth were exhausted, skipping to this happy ending prompted feelings of gratitude and optimism before they went home. Among the scenes that the youth repeatedly expressed joy in rehearsing was one in which they sang the Canadian national anthem 
together. They felt peace and a sense of healing in hearing their own voices uniformly come together in a form of their choice, to freely and openly express their gratitude and love for the country that helped rescue them: [Click here to see the National Anthem scene]. As we drove the youth back and forth for the rehearsals, we would all sing together during the ride and they would look so cheerful and joyful.

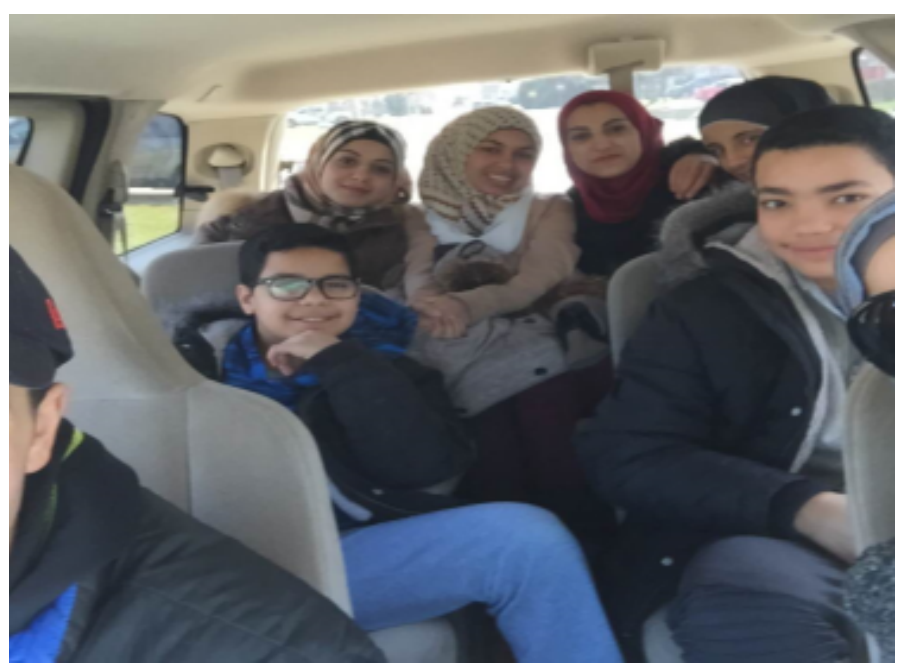

Figure 4.

Carpooling.

Civic agency and engagement. The collective nature of the project, of creating a single story from the memories of several youth, demanded genuine collaborative engagement from the youth. Getting a consensus for the script and visual performance of the scenes was challenging. It forced participants to make hard decisions about how their personal stories would be told, so that it would fit in with the larger story. The artistic direction also assisted the team in weaving the stories of this drama, Quilt of Shared Stories, as the play was later named. For example, one of the youth was assigned to be a journalist, reporting live from one of the cities and interviewing children - providing youth the opportunity to tell their experiences independently while also contributing to the broader theme of empowerment through sharing their untold stories. [Click here to see the "Reporting Live" scene]

One of the merits of this teamwork was the youth's increased dedication to the project. It reminded them of their common end goal: to reclaim 
their narratives so that they could reconcile their tragic memories with new understandings while bridging communication gaps with members in their new society. This was the strongest way to motivate the youth to stay committed to the project and resolve any conflicts that arose. Since the youth were all eager to share their stories, they worked hard to make sure that the performance would go on and would be brought to light.
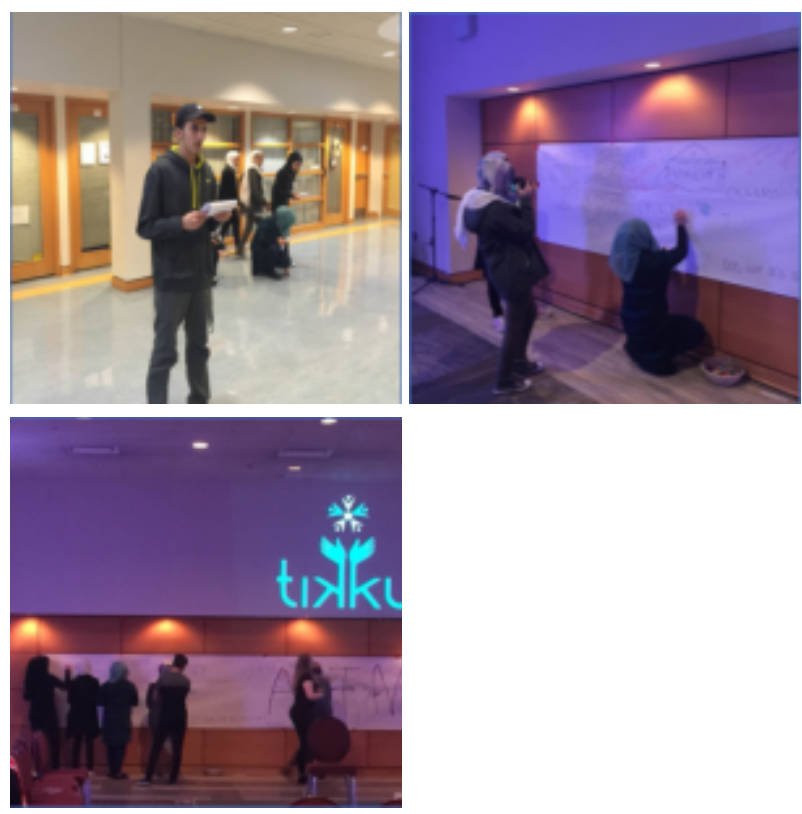

Figure 5. The day of the performance.

\section{The Play Performance}

On the morning of April 5, 2017, I bumped into Lina on the pathway leading to the building on campus where the Tikkun Youth Symposium was taking place. She was rushing out to her vehicle to give a lift to one of the youth whose carpool arrangement did not work as planned. I ran up to the event hall and began to welcome the youth as they arrived with their parents who 
joined to support them. Charlotte's face had the sweetest, reassuring smile as she tried to calm the youth who were anxious. As we waited for the program to start, we ran a last-time rehearsal with the youth before they went up on stage for their performance.

"What was it like performing the play?" I asked Randa.

It was a unique experience... no words can begin to describe my mixed feelings... I was proud of myself and my friends. We were performing in a new language, in a country we had only recently come to... My broken self was mending as random images of my past life ran in the back of my mind... I felt my heart pounding fast and loud, my legs were shaking, not with fear like it used to in the past, but with pride and happiness this time... I felt like I was speaking to the whole world, telling them that I have seen war, I have been through trauma and misery, but here I am still standing and "opening my arms to life" to start again.

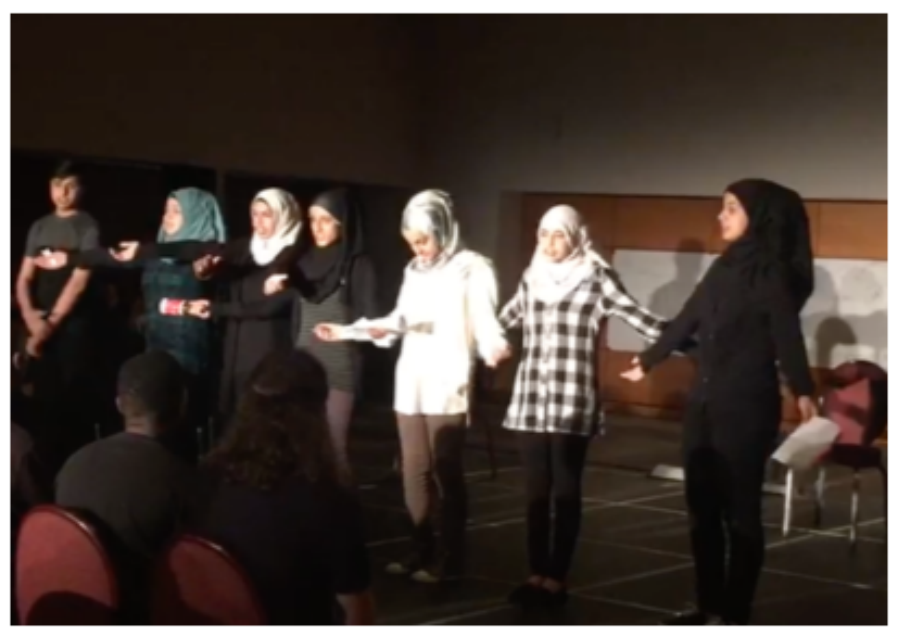

Figure 6. On stage.

\section{Reflective Analysis}

Randa's narratives telling the story of her first year of settlement as a refugee, highlight two interwoven themes of a young refugee's: (1) civic 
engagement; and (2) journey of healing and reconciliation. Each of these themes are unpacked and discussed here.

\section{Refugee Youth's Civic Engagement}

Dislocation from their homeland and relocating to a new country impact the quality of life refugee youth live for many years to come. While it is a harsh experience for many, some show strength through civic engagement and an active search for healing. The young Syrian refugees who participated in the play project demonstrated high ambitions for making a difference and a strong desire to bridge communication gaps within the community. Through the narrative life space of Randa, we explore the sources of motivation and civic agency of those youth within the three dimensions of time, interaction, and space (Clandinin \& Connelly, 2000).

As seen from a narrative perspective, "[n]arrative phenomena are not seen as existing in the here and now but, rather, are seen as flowing out of the past and into the future" (Xu \& Connelly, 2009, p. 224). Past experiences of the youth's civic engagement in their home country continue to influence their present and future civic agency and level of engagement.

In exploring Randa's civic agency through the continuum of time, it is clear that she had been exposed to the concept of youth civic engagement during the evolving stages of the Syrian conflict, which began with a youthled revolt in her hometown. Her past experience could be perceived as a negative one since it was widely met with persecution of the involved youth. However, witnessing injustices of war, being forced to leave home, and feelings of oppression elevated her civic agency and motivated her to make a difference and contribute to protecting public values.

She was ready to put this civic agency to use as the opportunities presented themselves to her upon relocating to Canada. She and her friends started to tell stories of war in different mediums. They first documented their stories in the form of a book and then presented them as a living library during the summer camp they participated in. They eventually saw great value in telling their stories as they received public acceptance and encouragement. This gave rise to their increased desire to share stories of war and survival with a wider audience which took the form of a play performance in the Tikkun Youth Symposium. This artistic platform of 
expression amplified their message to previously inaccessible audiences by crossing language barriers.

For Randa, having been a sociable and outgoing young girl in Syria, speaking up and getting involved in the wider community had been previously met with acceptance and appreciation. This had increased her confidence that she could be a valuable member of society. She even considered herself mature for her age because friends and family members would seek her advice on general and personal issues.

While Randa had a burning desire to connect with schoolmates and make friends upon leaving Syria, she felt helpless as she perceived society in Jordan as unwelcoming and blaming her and her people for abandoning their country. Her hopes and dreams were on the verge of being buried as she spent her school days in segregation and isolation.

Fortunately, as she moved to Canada and was met with more welcoming and supportive social settings, her civic agency was re-ignited and brought to action as she found the opportunity to tell her story and the stories of her people. She valued the power of sharing stories. She frequently remembered elder members of her family creating moments of deep connection with their youth during the most negative events of war by making time to pass down the history of the previous generations. Randa's value for the role of oral history and traditions, perceived as a trust bestowed upon their generation, contributed to her sense of civic agency in Canada. This was depicted as a bonfire in the play where the youth wanted to share and pass on their life stories with the audience. They had two driving goals: to bring awareness about the circumstances of war and the struggles of their people, and to create better social opportunities for themselves among their new community.

Randa and her friends felt a strong sense of responsibility as members of their families emphasized that youth have a responsibility to become stronger and capable of reclaiming their homeland in the future. Randa wished to prove her ability to be amongst those youth who make a difference. While she felt gratitude upon resettling in Canada for living in peace and being given the opportunity to go back to school and live a normal life, she continued to feel obliged to raise awareness about the circumstances of war her people were still experiencing in Syria.

Furthermore, in an effort to build bridges between herself, her newcomer friends, and those schoolmates whom she thought knew little about their 
traditions and values, she felt a need to engage in this form of action to bring understanding.

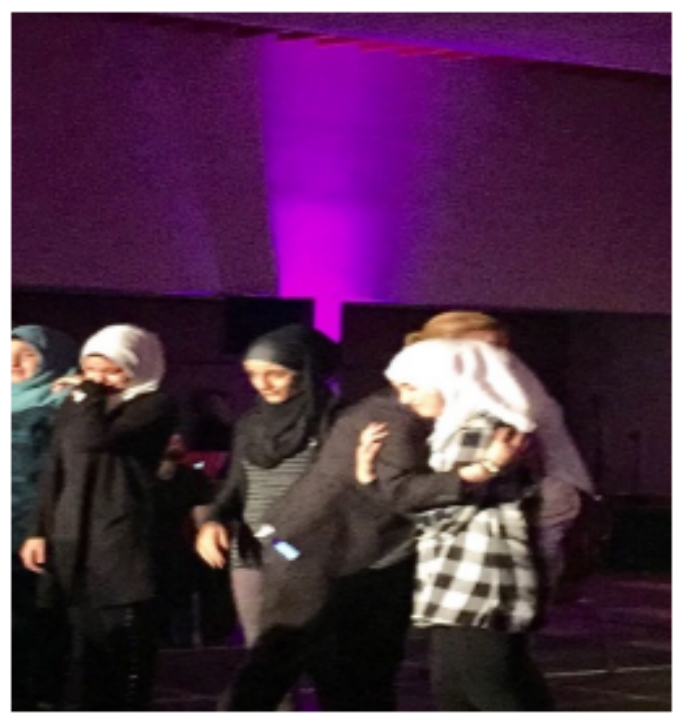

Figure 7. Play

closing.

It was emotional... I saw many hands wiping off tears as my friends and I performed... we received the most moving round of applause from the audience... It wasn't just a feeling of pride I felt that moment. I felt like I belonged... I felt surrounded with real peace, love, and trust. I could literally feel the great energy in the room.

\section{Refugee Youth's Journey of Healing and Reconciliation}

While the unique individual traits of each young refugee define the personal dimension of their lived experiences, "the social fabric that forms the framework of a person's life" (Andrews, 2007, p. 493) defines the social dimension. Therefore, it is impossible to understand the individual experiences of a young refugee's transition without first understanding the context of their personal/social interactions during the transition time period (Clandinin \& Connelly, 2000).

On a personal level. Syrian youth who were raised in the city of Dara'a 
lived in tight-knit communities which made them accustomed to the interdependent communal lifestyle. There was little need for developing new social relationships outside of existing close and caring bonds and extended family relations.

Relocating to Jordan and leaving her circles of social support increased Randa's need for affiliation to a group identity in search of care and protection. In turn, the challenges she faced in making friends upon her relocation led Randa to develop feelings of loneliness and anxiousness.

Having observed Randa's social interactions for over two years, it became clear that on a personal level she was a sociable young girl who found joy and comfort in having friends and engaging with the community. This implies that the struggles she experienced in making friends in Jordan were unlikely due to personal factors alone, but more likely resulted from a combination of personal and social factors.

On a social level. When she moved to Jordan, Randa was bound by the walls of her house for eight months and segregated from the rest of society. At her first attempt to go out, she faced integration barriers due to the social context of her specific placement in the private school she attended. In her narratives describing this transition period, Randa expressed feelings of alienation, instability, and uncertainty. Like most youth in similar circumstances, Randa perceived her school placement in Jordan only as a temporary one. Such feelings of weakness and lack of independence became associated with the place of her temporary residence and school where she received little support and struggled to keep whatever remained of her strength and resilience. However, in Canada, where she received more support and was able to relate to other people, she began a journey of healing.

Randa's journey of healing began upon her arrival in Canada. The support her family received from the government and the community made her feel like Windsor was a second home to them; thus, she became generally motivated to contribute to the betterment of society. She began to make friends shortly after, since living in close proximity to the residence of several other newcomer school acquaintances facilitated developing friendships in school and beyond. They would ride the school bus together every day and meet to spend time together on weekends and summer days when school was off.

In addition, the contextual differences between the school she attended in Jordan and her school in Canada are relevant to understanding her healing 
process through the transition. The diversity in her Canadian school promoted a sense of affiliation and belonging as she was able to make friends with schoolmates who shared similar experiences. She felt her experiences of trauma and war acknowledged not only by her new friends, but also by people from the wider community who showed empathy and support.

While the diverse makeup of Randa's Canadian high school helped her reconcile past challenging experiences of isolation and alienation, she continued to face challenges of integration due to the lack of cross-cultural competence among some schoolmates. Randa's narratives indicate that at times she felt judged by peers on the basis of stereotypes and misconceptions. Therefore, she felt a need for raising cross-cultural awareness to facilitate the overall social adjustment of herself and other newcomer friends.

The summer camp that Randa attended shortly after her arrival in Windsor provided her and her friends the first opportunity to realize that people in the community would be interested in learning about their experiences. She quickly discovered that there was no need for her to live with pain and feel ashamed or guilty for having left a war zone as she had previously felt. However, her love for her homeland and her loyalty for those she left behind motivated her to tell more about the negative impacts of war.

Eventually, Randa's involvement in the drama performance helped her in the journey of healing from past tragedies through sharing her stories and reconciling her understanding of civic engagement in Syria with that of Canada. The artistic platform provided Randa and her friends a medium for connecting on a deeper and more personal level. It also empowered them to amplify their voices and concerns, and to re-imagine themselves as engaged citizens initiating social change and raising awareness (Charmaraman, 2013). Through her participation in the play project, she felt a sense of fulfillment derived from feelings of productivity and her desire to contribute to developing cross-cultural understanding. This clearly impacted her overall social adjustment because she also felt the acceptance and the support of the wider community.

On an academic level. Given the unstable life circumstances most refugee children and youth experience during war, their schooling may have been interrupted for months or years before resettling. This was the case with Randa who was out of school for almost a year before she enrolled in school again in Jordan. In most cases, this impacts the learning and motivation for 
resuming education upon resettling in the host country and could cause academic barriers at the time of re-joining school.

For Randa, the sense of affiliation and belonging she developed upon relocating to Canada provided for an easier transition into school. While Randa's dedicated work ethic was influenced by her upbringing emphasizing the value for education - her work within the play project became an additional source of motivation for academic achievement. As her narratives indicate, she was encouraged by the team's pride in her academic accomplishments.

\section{Closing Statement}

While Randa's story of healing through civic engagement cannot represent the healing experiences of all young Syrian refugees, her story nonetheless provides insights on how civic engagement could be a source of healing and reconciliation for youth survivors of tragic experiences.

Randa's story reminds us that young newcomer refugees inevitably face challenges throughout the transition. However, her experience of healing through civic engagement provides guidance to members of the host society on the significance of encouraging young refugees' involvement in social endeavors. It portrays the impact of civic engagement on raising young refugees' confidence through finding their areas of strength in meaningful and purposeful ways.

Randa's story reveals a clear relationship between the young refugees' feelings of affiliation and belonging and their ability to heal from past tragic experiences of war and relocation. While individual personal qualities contribute to their social and academic adjustment upon resettlement, we learn that social contexts play a big role in facilitating or hindering their healing and reconciliation. From exploring Randa's story, we are also reminded that some heal through civic engagement as they come to accept their shortcomings and focus more on how they could contribute to the wider community.

As Randa's story describes, living in war-torn countries and areas of political conflict deeply affects people's mental wellbeing by forcing them to experience trauma and build fear. For youth survivors to overcome the post- 
traumatic effects of war and stay mentally healthy, they need to realize that there is no reason to hold on to their fears and doubts. They need to feel welcomed and accepted and this is brought to the forefront in Randa's story. This can be accomplished through increasing opportunities for positive social interactions in schools and the wider community. Randa's story also underscores the importance of cross-cultural understanding in building harmony and acceptance within diverse communities.

Finally, this narrative inquiry affirms that refugee youth feel immense gratitude towards the host countries and their people who have rescued them from war and provided them with a chance to live a normal life. In return, the gratitude these youth feel creates a strong sense of civic agency which could positively serve the host communities if provided with opportunities in appropriate mediums to build on their talents. For many, survival creates resilience and determination that could make them valuable citizens to their new societies.

\section{References}

Andrews, M. (2007). Exploring cross-cultural boundaries. In D. J. Clandinin (Ed.), Handbook of narrative inquiry (pp. 489-511). London, UK: Sage.

Ayoub, M., \& Zhou, G. (2016). Somali refugee students in Canadian schools: Pre-migration experiences and challenges in refugee camps. Comparative and International Education, 45(3), Art. 5. Retrieved from https://ir.lib.uwo.ca/cie-eci/vol45/iss3/5

Charmaraman, L. (2013). Congregating to create for social change: Urban youth media production and sense of community. Learning, Media $\varepsilon$ Technology, 38(1), 102-115. doi:10.1080/17439884.2011.621956

Ciuffetelli Parker, D., \& McQuirter Scott, R. (2010). From mentorship to tenureship: A storied inquiry of two academic careers in education. Mentoring \& Tutoring: Partnership in Learning, 18(4), 405-425. doi:10.1080/ 13611267.2010 .511849

Clandinin, D. J., \& Connelly, F. M. (1988). Studying teachers' knowledge of classrooms: Collaborative research, ethics, and the negotiation of narrative. Journal of Educational Thought, 22(2A), 269-282. Retrieved from https://www.jstor.org/stable/23768371 
Clandinin, D. J., \& Connelly, F. M. (1992). The teacher as curriculum-maker. In P. W. Jackson (Ed.), Handbook of research on curriculum: A project of the American Educational Research Association (pp. 363-401). New York, NY: Macmillan.

Clandinin, D. J., \& Connelly, F. M. (2000). Narrative inquiry: Experience and story in qualitative research. San Francisco, CA: Jossey-Bass.

Connelly, F. M., \& Clandinin, D. J. (1990). Stories of experience and narrative inquiry. Educational Researcher, 19(5), 2-14. doi:10.3102/ 0013189X019005002

Coulter, C. A. \& Smith, M. L. (2009). Discourse on narrative research: The construction zone: Literary elements in narrative research. Educational Researcher, 38(8), 577-590. doi:10.3102/0013189X09353787

Craig, C. J. (2013). Coming to know in the "eye of the storm": A beginning teacher's introduction to different versions of teacher community. Teaching and Teacher Education, 29, 25-38. doi:10.1016/j.tate.2012.08.003 Dewey, J. (1938). Experience and education. New York, NY: Kappa Delta Pi.

Ehntholt, K. A., \& Yule, W. (2006). Practitioner review: Assessment and treatment of refugee children and adolescents who have experienced warrelated trauma. Journal of Child Psychology and Psychiatry, 47(12), 1197-1210. doi:10.1111/j.1469-7610.2006.01638.x

Elbaz-Luwisch, F. (2004). Immigrant teachers: Stories of self and place. International Journal of Qualitative Studies in Education, 17(3), 387-414. doi:10.1080/0951839042000204634

Elkord, N. (2017). Arab immigrant high school students' perceptions of their high school experiences in Canada: A narrative inquiry (doctoral dissertation). University of Windsor, Windsor, ON. Retrieved from https://scholar.uwindsor.ca/etd/7252

Feldman, M. S., Skoldberg, K., Brown, R. N., \& Horner, D. (2004). Making sense of stories: A rhetorical approach to narrative analysis. Journal of Public Administration Research and Theory, 14(2), 147-170. doi:10.1093/jopart/ muh010

Government of Canada. (2017a). \#WelcomeRefugees: Key figures. Retrieved from https://www.canada.ca/en/immigration-refugees-citizenship/ services/refugees/welcome-syrian-refugees/key-figures.html

Government of Canada. (2017b). How Canada's refugee system works.

Retrieved from https://www.canada.ca/en/immigration-refugeescitizenship/services/refugees/canada-role.html

George, A. (2003). Syria: Neither bread nor freedom. London: Zed Books. 
Haddad, B. (2012). Business networks in Syria: The political economy of authoritarian resilience. Stanford, CA: Stanford University Press.

Hamilton, C., \& Flanagan, C. (2007). Reframing social responsibility within a technology-based youth activist program. American Behavioral Scientist, 51(3), 444-464. doi:10.1177/0002764207306070

Janzen, R., \& Ochocka, J. (2003). Immigrant youth in Waterloo region. In P. Anisef \& K. M. Kilbride (Eds.), Managing two worlds: The experiences \& concerns of immigrant youth in Ontario (pp. 37-68). Toronto, ON: Canadian Scholars' Press.

Khoury, P. S. (1991). Syrian political culture: A historical perspective. In R. T. Antoun \& D. Quataert (Eds), Syria: Society, culture and polity (pp. 13-27). Albany, NY: University of New York Press.

Lee, S. J. (2005). Up against whiteness: Race, school, and immigrant youth. New York, NY: Teachers College Press.

Manavathu, M., \& Zhou, G. (2012). The impact of differentiated instructional materials on English Language Learner (ELL) students' comprehension of science laboratory tasks. Canadian Journal of Science, Mathematics and Technology Education, 12(4), 334-349. doi:10.1080/14926156.2012.732255

Mishler, E. (1990). Validity in inquiry-guided research: The role of exemplars in narrative studies. Harvard Educational Review, 60(4), 415-442. doi:10.17763/haer.60.4.n4405243p6635752

Multicultural Council of Windsor and Essex County. (2018). Our mission. Retrieved from http://themcc.com/

Pace, J., \& Landis, J. (2009). The Syrian opposition: The struggle for unity and relevance, 2003-2008. In F. H. Lawson (Ed.), Demystifying Syria (pp. 120-143). London: Saqi in association with London Middle East Institute SOAS.

Rabo, A. (2005). A shop of one's own: Independence and reputation among traders in Aleppo. London: I.B. Tauris.

United Nations. (2019). Refugees. Retrieved from https://www.un.org/en/ sections/issues-depth/refugees/index.html

$\mathrm{Xu}, \mathrm{S}$. J., \& Connelly, F. M. (2009). Narrative inquiry for teacher education and development: Focus on English as a foreign language in China. Teaching and Teacher Education, 25, 219-227. doi:10.1016/j.tate.2008.10.006

Xu, S. J., \& Connelly, F. M. (2010). Narrative inquiry for school-based research. Narrative Inquiry, 20(2), 349-370. doi:10.1075/ni.20.2.06xu 